\title{
Pengaruh Metode Pembelajaran Karya Kelompok Terhadap Keterampilan Proses Sains Dengan Kovariabel Kemampuan Berpikir Kreatif Siswa Pada Mata Pelajaran Biologi
}

\author{
Theodora Sarlotha Nirmala Manu, Fransina Th. Nomleni \\ piva_mn@yahoo.com, nomlenifince@gmail.com \\ FKIP Biologi, Universitas Kristen Artha Wacana Kupang
}

\section{The Effect of Group Workshop Learning Method Towards Student's Science Process Skills With A Covariable Of Student's Creative Thinking Ability in Biology}

\begin{abstract}
The purpose of this research is to determine: (1) the difference of the science process skills of students learning using group workshop method with students using the discussion method; (2) differences in the condition above, after the ability of creative thinking covariable is controlled; and (3) the contribution of creative thinking covariable towards the science process skills of students. This experimental research used the post-test only control group design, with the population of 210 students of grade XI SMA Negeri 7 Kota Kupang. The total samples were 140 students, distributed in 2 experimental classes and 2 control classes. The data was collected by observing the science process skills using creative thinking skill test. The data were analyzed in descriptive and inferential statistics using one-way covariance analysis (Anacova). The result indicated that: (1) there was a significant difference of science process skills between the students learning using the group workshop method with students learning using the discussion method with an F value of 50,964; $p \leq 0.05$.; (2) Having controlled the student's creative thinking ability, there was a significant difference between student's science process skills among students who enrolled in group workshop method with the students enrolled in the discussion method; where F=17.822; $p \leq 0,05$. (3) Creative thinking ability contributed to the science process skills with the coefficient of determination equals to $r 2=(0,430) 2=0,185$ or $18,5 \%$. The results indicate that the application of group workshop methods has positive effect on improving students' science process skills and creative thinking skills.
\end{abstract}

Keywords: science process skills, creative thinking abillity, group workshop learning method

Received date: 14 November 2017

Article Info

Revised date: 4 Maret 2018

Accepted date: 4 Mei 2018

\section{PENDAHULUAN}

Perubahan jaman dan tuntutan masyarakat mendorong peningkatkan kualitas pendidikan untuk mampu menghasilkan sumber daya manusia yang berkualitas dan mampu bersaing. Sebagaimana yang diungkapkan oleh Mulyasa (2009:4), dalam tataran mikro pendidikan harus mampu menghasilkan sumber daya manusia yang berkualitas dan profesional, termasuk di dalamnya kebutuhan dunia kerja dan respon terhadap perubahan yang terjadi dalam masyarakat. Upaya untuk meningkatkan mutu pendidikan membutuhkan proses pembelajaran yang optimal sehingga tercapai tujuan yang diharapkan.

Menurut UU No. 23 Tahun 2003 tentang Sistem Pendidikan Nasional, pembelajaran adalah proses interaksi peserta didik dengan pendidik dan sumber belajar pada suatu lingkungan belajar. Pembelajaran merupakan proses penyediaan kondisi yang mengakibatkan terjadinya interaksi dalam proses belajar pada diri peserta didik dengan guru. Upaya untuk mengembangkan kompetensi peserta didik memerlukan adanya kerjasama antartiap komponen dalam dunia pendidikan untuk mencapai niat tersebut. 
Pengaruh Metode Pembelajaran Karya Kelompok Terhadap Keterampilan Proses Sains Dengan

Kovariabel Kemampuan Berpikir Kreatif Siswa .... (Theodora S. N. Manu, F. Th. Nomleni)

Biologi merupakan salah satu rumpun ilmu dalam Ilmu Pengetahuan Alam (IPA) memiliki kajian pada makhluk hidup dan segala aspek dalam kehidupannya.Mata pelajaran biologi berisi pelajaran yang menyenangkan karena selalu berhubungan dengan kehidupan makhluk hidup yang ada di sekitar. Menghafal materi sains tanpa proses penalaran tidak lagi cukup efektif untuk mengembangkan potensi siswa. Salah satu cara yang digunakan untuk mengembangkan potensi siswa adalah mengembangkan keterampilan proses sains.

Keterampilan proses sains merupakan salah satu keterampilan yang dapat dikembangkan dalam pembelajaran biologi. Pembelajaran biologi membutuhkan keterampilan proses sains karena keterampilan proses melibatkan pengalaman-pengalaman langsung sebagai pengalaman belajar. Melalui pengalaman langsung, seseorang dapat labih menghayati proses atau kegiatan yang sedang dilakukan. Pada dasarnya siswa telah memiliki keterampilan proses sains misalnya keterampilan bertanya, hipotesis, investigasi, observasi, klasifikasi, prediksi, interpretasi dan komunikasi (Dimyanti \& Mudjiono, 2009). Namun keterampilan-keterampilan tersebut terkadang tidak muncul secara maksimal karena belum adanya penggunaan metode pembelajaran yang mampu memunculkan keterampilan proses sains siswa.

Kenyataan yang terjadi, pembelajaran biologi di SMA Negeri 7 Kota Kupang cenderung hanya mengembangkan beberapa keterampilan siswa, misalnya keterampilan berkomunikasi dan observasi yang dilakukan melalui diskusi kelompok, keterampilan observasi melalui kegiatan praktikum. Keterampilan proses sains seperti: bertanya, hipotesis, investigasi, klasifikasi, prediksi, interpretasi belum nampak dalam kegiatan pembelajaran. Hal ini disebabkan oleh beberapa faktor diantaranya: penggunaan metode pembelajaran yang kurang tepat untuk mengembangkan keterampilan proses sains siswa. Pembelajaran di kelas hendaknya memberikan kesempatan kepada siswa untuk mengembangkan keterampilanketerampilan yang ada pada diri siswa. Penggunaan metode pembelajaran yang diyakini mampu memunculkan keseluruhan keterampilan proses sains siswa adalah melalui metode pembelajaran karya kelompok. Metode karya kelompok merupakan metode pembelajaran yang mengembangkan aspek produk, proses dan sikap sains (Suyono dan Hariyanto, 2015). Keunggulan dari metode ini adalah mampu untuk mengembangkan keterampilan proses dan peningkatan hasil belajar siswa melalui tugas proyek yang dikerjakan siswa.

Selain metode pembelajaran yang harus diperhatikan oleh guru, tentunya ada faktor lain juga diduga turut mempengaruhi keterampilan proses sains yaitu kemampuan berpikir kreatif. Kemampuan berpikir kreatif merupakan bakat yang secara potensial dimiliki oleh setiap orang, yang dapat diidentifikasi dan dipupuk melalui pendidikan yang tepat (Munandar, 2004). Pembelajaran biologi yang baik akan mengotimalkan dan mengembangkan kemampuan berpikir kreatif siswa. Kemampuan berpikir kreatif diistilahkan sebagai kreativitas yang secara operasional merupakan suatu proses yang tercermin dari kelancaran, kelenturan, orisinalitas dan elaborasi dalam berpikir. Belajar kreatif memungkinkan hasil belajar dapat dialihkan ke dalam berbagai situasi lain yang unik dan tidak biasa melalui proses transfer belajar (transfer of learning). Keunggulan siswa yang kemampuan berpikir kreatifnya tinggi adalah mereka mempunyai cara yang bervariasi untuk menghadapi masalah yang bervariasi. Siswa dengan kemampuan berpikir kreatif tinggi dapat keluar dari masalah dengan mendayagunakan informasi dan pengetahuan yang dimilikinya secara kreatif digunakan untuk memecahkan masalah, sebaliknya siswa dengan kemampuan berpikir kreatif rendah hanya akan mempelajari satu cara untuk memecahkan masalah dari materi pelajaran. Kesulitan akan muncul apabila masalah yang dihadapi merupakan masalah yang sama sekali baru, siswa yang kemampuan berpikir kreatifnya rendah hanya dapat memecahkan masalah apabila informasi yang dimiliki dapat secara langsung dimanfaatkan untuk menjawab soal. 
Dalam penelitian ini, akan dikaji pengaruh metode pembelajaran karya kelompok terhadap keterampilan proses sains dengan mempertimbangkan kemampuan berpikir kreatif siswa. Dengan melakukan analisis kovarian (anacova) diharapkan akan diperoleh perbedaan hasil keterampilan proses sains siswa dengan metode karya kelompok dengan metode diskusi serta besarnya kontribusi kovariabel kemampuan berpikir kreatif terhadap keterampilan proses sains siswa.

Tujuan penelitian ini adalah untuk: (1) Untuk mengetahui perbedaan keterampilan proses sains siswa yang mengikuti pembelajaran dengan metode karya kelompok dengan siswa yang mengikuti pembelajran dengan metode diskusi; (2) Untuk mengetahui perbedaaan keterampilan proses sains siswa yang mengikuti pembelajaran dengan metode karya kelompok dengan siswa yang mengikuti pembelajran dengan metode diskusi, setelah kovariabel kemampuan berpikir kreatif dikendalikan; (3) Untuk mengetahui kontribusi kovariabel kemampuan berpikir kreatif terhadap keterampilan proses sains.

\section{KAJIAN PUSTAKA}

Metode pembelajaran karya kelompok adalah salah satu metode pembelajaran yang berpusat kepada siswa (student center) dimana siswa diberikan tugas untuk menyelesaikan suatu proyek melalui kerja sama antara kelompok (Suyono dan Hariyanto, 2015). Menurut Sagala (2006), metode kerja kelompok adalah cara pembelajaran dimana siswa dalam kelas dibagi dalam beberapa kelompok, dimana setiap kelompok dipandang sebagai satu kesatuan tersendiri untuk mempelajari materi pelajaran yang telah ditetapkan untuk diselesaikan secara bersama-sama.

Materi pelajaran yang dikerjakan secara bersama-sama dalam kelompok itu diberikan atau disiapkan oleh guru. Guru hanya sebagai fasilitator dalam pembelajaran (Rahmadani, 2017). Materi yang diberikan harus cukup kompleks isinya dan cukup luas ruang lingkupnya sehingga dapatdibagi-bagi menjadi bagian yang cukup memadai bagi setiap kelompok. Materi hendaknya membutuhkan bahan dan informasi dari berbagai sumberuntuk pemecahannya.

Kelompok dapat dibentuk berdasarkan perbedaan individual dalam kemampuan belajar, perbedaan bakat dan minat belajar, jenis kegiatan,materi pelajaran, dan tujuan yang ingin dicapai. Berdasarkan tugas yang harus diselesaikan, siswa dapat dibagi atas kelompok paralel yaitu setiapkelompok menyelesaikan tugas yang sama, dan kelompok komplementerdimana setiap kelompok berbeda-beda tugas yang harus diselesaikan. Tugas yang diberikan merupakan tugas yang dapat dikerjakan di kelas dan di luar kelas serta memerlukan berbagai sumber yang tersedia di luar sekolah. Guru menugasi siswa berdasarkan pembagian masalah. Setiap masalah yang diberikan merupakan aspek yang menarik untuk dibahas.

Peran guru dalam pembelajaran adalah sebagai berikut:

a) Organisator, yang mengorganisasi siswa untuk kegiatan pembelajaran;

b) Observer, mengamati dinamika kelompok, laju diskusi kelompok, partisipasi anggota kelompok, memberikan saran atau nasihat yang berguna bagi siswa;

c) Advisor, memberikan saran-saran tentang bagaimana menyelesaikan tugas-tugas kelompok;

d) Penilai, menilai proses kelompok bersama-sama kelompok dan memberikan nilai akhir.

Dalam metode pembelajaran karya kelompok, kelas dibagi menjadi beberapa kelompok. Setiap kelompok terdiri dari beberapa orang siswa dan mendapat pembagian tugas proyek yang akan dikerjakan. Guru melihat pentingnya sebuah masalah untuk dibahas dan memerlukan berbagai sudut pandang kelompok tentang alternatif pemecahan masalah. Guru 
Pengaruh Metode Pembelajaran Karya Kelompok Terhadap Keterampilan Proses Sains Dengan

Kovariabel Kemampuan Berpikir Kreatif Siswa .... (Theodora S. N. Manu, F. Th. Nomleni)

bisa saja memberikan tugas yang sama bagi seluruh kelompok atau berbeda untuk setiap kelompok.

Langkah-langkah kegiatan pembelajaran dengan metode pembelajaran karya kelompok menurut Suyono dan Hariyanto (2015) adalah sebagai berikut:

a) Memilih materi pembelajaran yang cukup tingkat kesulitan dan kompleksitasnya sehingga dapat dipilih sebagai bahan proyek yang akan dikerjakan oleh siswa;

b) Merancang dan menentukan tema masalah yang akan dikerjakan siswa;

c) Membagi kelas dalam kelompok-kelompok;

d) Menjelaskan pelaksanaan pengerjaan proyek kepada siswa termasuk hal-hal yang akan dikerjakan siswa di sekolah dan di luar sekolah;

e) Guru mengamati dinamika kelompok, kemajuan diskusi kelompok dan memberikan pengarahan kepada siswa;

f) Siswa mempresentasikan hasil laporan kerja setiap kelompok;

g) Bersama-sama membuat kesimpulan dan penilaian terhadap hasil kerja kelompok.

Keunggulan atau kekuatan dari metode pembelajaran karya kelompok menurut (Suyono dan Hariyanto, 2015) adalah:

a) Siswa akan terdorong untuk mempraktikan pembelajaran aktif;

b) Siswa merasa tertantang untuk menyelesaikan tugasnya;

c) Siswa terbiasa untuk menggunakan sumber belajar yang tersedia di luar sekolah;

d) Membantu siswa untuk menyelesaikan tugas-tugas yang kompleks.

Sebaliknya, kelemahan dari metode pembelajaran karya kelompok menurut (Suyono dan Hariyanto, 2015) adalah

a) Jarang ada guru yang mampu merancang dan memikirkan tugas-tugas atau proyek kelompok;

b) Memakan waktu yang lama;

c) Jika proyek terlalu sukar ada kemungkinan tidak dapat selesai pada waktunya;

d) Di luar sekolah, guru sulit mengamati dinamika kelompok.

Keterampilan proses sains adalah perangkat kemampuan kompleks yang biasa digunakan oleh para ilmuwan dalam melakukan penyelidikan ilmiah ke dalam rangkaian proses pembelajaran. Menurut Dahar (1996), keterampilan proses sains adalah kemampuan siswa untuk menerapkan metode ilmiah dalam memahami, mengembangkan dan menemukan ilmu pengetahuan. Keterampilan proses sains sangat penting bagi setiap siswa sebagai bekal untuk menggunakan metode ilmiah dalam mengembangkan sains serta diharapkan memperoleh pengetahuan baru atau mengembangkan pengetahuan yang telah dimiliki.

Manfaat dari keterampilan proses sains dalam pembelajaran dasar dan menengah adalah sebagai berikut:

a) Memiliki manfaat dalam memecahkan masalah yang dihadapi dalam kehidupan

b) Memberi bekal kepada siswa untuk membentuk konsep sendiri dan cara bagaimana mempelajari sesuatu

c) Membantu siswa dalam pengembangan dirinya sendiri

d) Membantu siswa yang masih berada pada taraf perkembangan berpikir konkret.

e) Membantu siswa mengembangkan kreatifitasnya.

Aspek-aspek pada keterampilan proses sains yang akan diteliti menurut Dimyanti \& Mudjiono (2009) meliputi:

a) Mengamati (observasi)

Mengamati adalah proses pengumpulan data tentang fenomena atau peristiwa dengan menggunakan inderanya.

b) Mengelompokkan (Klasifikasi) 
Mengelompokkan adalah suatu sistematika yang digunakan untuk menggolongkan sesuatu berdasarkan syarat-syarat tertentu.

c) Menafsirkan (interpretasi)

Menafsirkan hasil pengamatan ialah menarik kesimpulan tentatif dari data yang dicatatnya.

d) Meramalkan (prediksi)

Meramalkan adalah memperkirakan berdasarkan pada data hasil pengamatan yang reliabel.

e) Mengajukan pertanyaan

Keterampilan proses mengajukan pertanyaan dapat diperoleh siswa dengan mengajukan pertanyaan apa, mengapa, bagaimana, pertanyaan untuk meminta penjelasan atau pertanyaan yang berlatar belakang hipotesis.

f) Merumuskan hipotesis

Hipotesis adalah suatu perkiraan yang beralasan untuk menerangkan suatu kejadian atau pengamatan tertentu.

g) Merencanakan penelitian

Keterampilan merencanakan percobaan, menentukan alat dan bahan yang akan digunakan dalam percobaan, menentukan variabel-variabel, menentukan. Demikian pula siswa perlu untuk menentukan apa yang akan diamati, diukur, atau ditulis, menentukan cara dan langkah-langkah kerja. Selanjutnya siswa dapat pula menentukan bagaimana mengolah hasil-hasil pengamatan.

h) Berkomunikasi

Keterampilan ini meliputi keterampilan membaca grafik, tabel, atau diagram dari hasil percobaan.Menggambarkan data empiris dengan grafik, tabel, atau diagram juga termasuk berkomunikasi.

Kemampuan berpikir kreatif merupakan respon dari stimulus terhadap suatu objek yang merupakan wawasan pola pikir seorang siswa yang dinyatakan dalam bentuk variasi dari respon tentang hal-hal yang terkait dengan pokok pembicaraan (Suastra,2006. Kreativitas merupakan bakat yang secara potensial dimiliki oleh setiap orang, yang dapat diidentifikasi dan dipupuk melalui pendidikan yang tepat (Munandar, 2004).Ciri-ciri kreativitas dapat ditinjau dari dua aspek yaitu:

a. Aspek Kognitif. Ciri-ciri kreativitas yang berhubungan dengan kemampuan berpikir kreatif/divergen (ciri-ciri aptitude) yaitu: 1) keterampilan berpikir lancar (fluency); (2) keterampilan berpikir luwes/fleksibel (flexibility); (3) keterampilan berpikir orisinal (originality); (4) keterampilan memperinci (elaboration); dan (5) keterampilan menilai (evaluation). Makin kreatif seseorang, ciri-ciri tersebut makin dimiliki (Williams, dalam Munandar, 2004).

b. Aspek Afektif. Ciri-ciri kreativitas yang lebih berkaitan dengan sikap dan perasaan seseorang (ciri-ciri non-aptitude) yaitu: (a) rasa ingin tahu; (b) bersifat imajinatif/fantasi; (c) merasa tertantang oleh kemajemukan; (d) sifat berani mengambil resiko; (e) sifat menghargai; (f) percaya diri; (g) keterbukaan terhadap pengalaman baru; dan (h) menonjol dalam salah satu bidang seni (Williams \& Munandar, 2004).

Model belajar mengajar kreatif telah banyak dikembangkan. Salah satu diantaranya adalah model Williams (dalam Munandar,2004), model ini menampilkan secara tigadimensional yaitu (1) dimensi kurikulum, (2) dimensi prilaku guru, (3) dimensi prilaku siswa. Dalam dimensi perilaku siswa meliputi delapan keterampilan, empat dari ranah kognitif dan empat dari ranah afektif. Kemampuan berpikir kreatif yang dimaksud dalam penelitian ini adalah berpikir lancar (kefasihan), berpikir luwes (fleksibel), berpikir orisinal (kebaruan), dan berpikir terperinci (elaborasi) yang dioperasionalisasikan sebagai berikut: 
Pengaruh Metode Pembelajaran Karya Kelompok Terhadap Keterampilan Proses Sains Dengan

Kovariabel Kemampuan Berpikir Kreatif Siswa .... (Theodora S. N. Manu, F. Th. Nomleni)

a) Berpikir Lancar dalam pemecahan masalah mengacu pada keberagaman (bermacammacam) jawaban masalah yang dibuat siswa dengan benar.

b) Berpikir Luwes dalam pemecahan masalah mengacu pada kemampuan siswa memecahkan masalah dengan menghasilkan gagasan-gagasan yang seragam, mampu mengubah cara atau pendekatan atau arah pikiran yang berbeda-beda.

c) Berpikir Orisinal dalam pemecahan masalah mengacu pada kemampuan siswa menjawab masalah dengan beberapa jawaban yang tidak lazim, yang lain daripada yang lain, atau yang jarang diberikan kebanyakan orang lain, tetapi bernilai benar atau satu jawaban yang tidak biasa dilakukan oleh individu (siswa) pada tahap perkembangan mereka atau tingkat pengetahuannya.

d) Berpikir terperinci dalam pemecahan masalah mengacu pada kemampuan siswa untuk mengembangkan, menambah, memperkaya suatu gagasan, memperinci detail-detail maupun memperluas suatu gagasan.

\section{METODE PENELITIAN}

Penelitian ini merupakan penelitian eksperimen semu; dengan desain "post-test only control group design'. Rancangan analisis data yang digunakan dalam penelitian ini adalah rancangan analisis kovarian (ANACOVA) satu jalan-satu kovariabel. Penelitian dilakukan di SMA Negeri 7 Kota Kupang-NTT pada semester genap tahun ajaran 2016/2017.Populasi adalah seluruh siswa kelas XI SMA Negeri 7 Kupang berjumlah 210 siswa. Pengambilan sampel penelitian menggunakan teknik random sampling dan dipakai dua kelas sebagai kelas eksperimen dan dua kelas sebagai kelas kontrol dengan jumlah 70 siswa. Tahapan pelaksanaan penelitian dilaksanakan sebagai berikut: (1) Tahapan Persiapan eksperimen meliputi: pembuatan silabus, RPP, instrument penelitian, melakukan uji coba instrumen, menguji validitas dan reliabiltas instrumen penelitian; (2) Tahapan pelaksanaan eksperimen; (3) Tahap pengumpulan data: meliputi kegiatan observasi keterampilan proses sains dan menyebarkan tes kemampuan berpikir kreatif pada kelas eksperimen dan kelas kontrol; dan (4) Tahapan Pengolahan data meliputi: uji prasyarat analisis, uji statistik deskriptif, uji hipotesis penelitian, dan penarikan kesimpulan.Teknik pengumpulan data adalah menggunakan observasi untuk mengukur keterampilan proses sains dan tes untuk mengukur kemampuan berpikir kreatif.Teknik analisa data menggunakan dua teknik analisis yaitu analisis statistik deskriptif dan analisis inferensial yaitu analisis kovarian (anakova) satu jalan-satu kovariabel. Analisis statistik deskriptif dapat mendeskripsikan masing-masing variabel penelitian sedangkan analisis kovarian (anakova) dapat menguji hipotesis yang diajukan. Adapun Hipotesis yang diajukan dalam penelitian ini adalah sebagai berikut :

a) Terdapat perbedaan keterampilan proses sains siswa yang mengikuti pembelajaran dengan metode karya kelompok dengan siswa yang mengikuti pembelajran dengan metode diskusi

b) Terdapat perbedaaan keterampilan proses sains siswa yang mengikuti pembelajaran dengan metode karya kelompok dengan siswa yang mengikuti pembelajran dengan metode diskusi, setelah kovariabel kemampuan berpikir kreatif dikendalikan

c) Terdapat kontribusi kovariabel kemampuan berpikir kreatif terhadap keterampilan proses sains 


\section{HASIL DAN PEMBAHASAN}

\section{Deskripsi Data Penelitian}

Deskripsi data setiap kelompok memaparkan ukuran pemusatan yang meliputi ratarata (mean), median, modus, standar deviasi, varians, rentangan, data maksimum, dan data minimum. Secara ringkas, hasil perhitungan skor keterampilan proses sains siswa dalam mata pelajaran Biologi dan kemampuan berpikir kreatif untuk kelas eksperimen (XI MIA ${ }_{1} \&$ XI MIA 4 ) dan kelas kontrol (XI MIA $\&$ XI MIA 3 ) Pada SMA Negeri 7 Kota Kupang dapat dilihat pada Tabel 1 .

Tabel 1.

Data Keterampilan Proses Sains dan Kemampuan Berpikir Kreatif Siswa

\begin{tabular}{|c|c|c|c|c|}
\hline Data Statistik & $\mathbf{Y A}_{1}$ & $\mathbf{Y A}_{2}$ & $\mathbf{X}_{1} \mathbf{A}_{1}$ & $\mathbf{X}_{1} \mathbf{A}_{2}$ \\
\hline Mean & 82,43 & 72,70 & 48,96 & 39,30 \\
\hline Modus & 85 & 77 & 50 & 38 \\
\hline Median & 83 & 72,50 & 50 & 38 \\
\hline SD & 6,491 & 9,374 & 5,412 & 4,579 \\
\hline Variance & 42,133 & 87,865 & 29,288 & 20,967 \\
\hline Skor Mininum & 67 & 52 & 38 & 30 \\
\hline Skor Maksimum & 96 & 91 & 60 & 49 \\
\hline Rentangan & 29 & 39 & 22 & 19 \\
\hline
\end{tabular}

\section{Keterangan:}

YA1 : keterampilan proses sains siswa yang mengikuti pembelajaran metode karya kelompok

YA2 : keterampilan proses sains siswa yang mengikuti pembelajaran metode ceramah.

X1A1 : kemampuan berpikir kreatif siswa yang mengikuti pembelajaran dengan metode karya kelompok

$\mathrm{X} 1 \mathrm{~A} 2 \quad$ : kemampuan berpikir kreatif siswa yang mengikuti pembelajaran dengan metode ceramah

Dari tabel 1 di atas, ditemukan bahwa penerapan metode karya kelompok lebih unggul dibandingkan dengan pembelajaran dengan metode ceramah. Distribusi frekuensi untuk Keterampilan proses sains dan kemampuan berpikir kreatif dapat dilihat pada diagram di bawah ini:

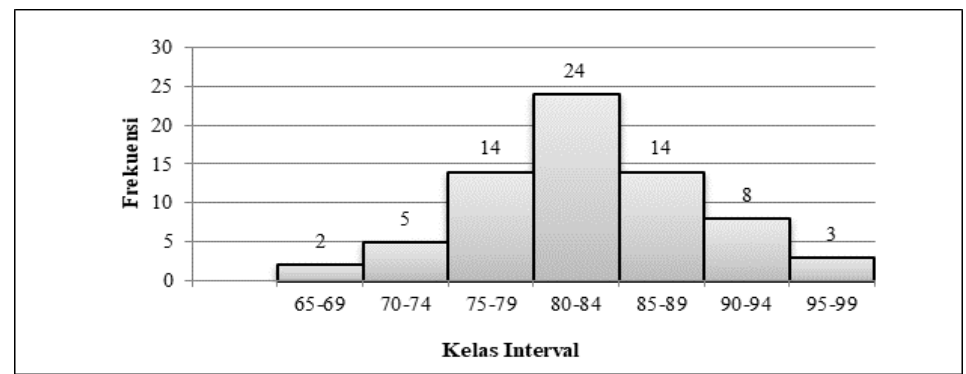

Gambar 1.

Keterampilan Proses sains kelas eksperimen (YA1)

Berdasarkan diagram di atas, menunjukkan bahwa 24 siswa $(34,28 \%)$ yang berada pada kelompok rata-rata hitung, 21 siswa (30\%) siswa memperoleh skor di bawah rata-rata hitung, dan 25 siswa $(35,71 \%)$ memperoleh skor di atas rata-rata. 
Pengaruh Metode Pembelajaran Karya Kelompok Terhadap Keterampilan Proses Sains Dengan Kovariabel Kemampuan Berpikir Kreatif Siswa .... (Theodora S. N. Manu, F. Th. Nomleni)

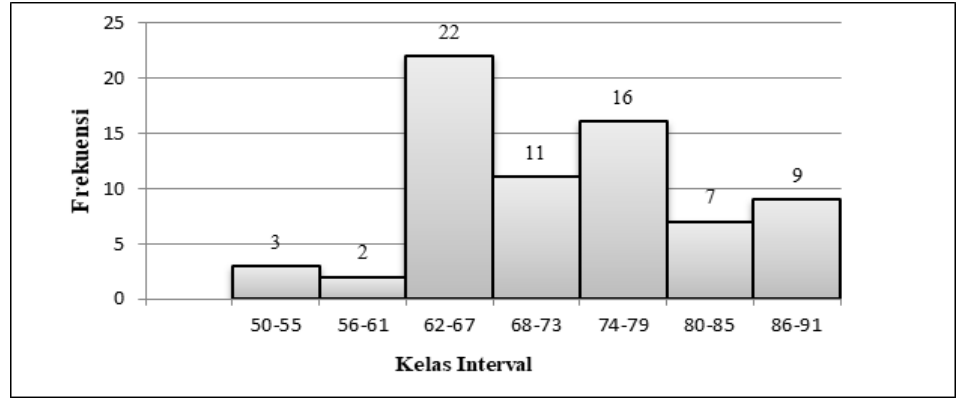

Gambar 2.

Keterampilan Proses Sains Kelas Kontrol ( $\left.\mathbf{Y A}_{2}\right)$

Berdasarkan diagram di atas, menunjukkan bahwa 11 siswa $(15,71 \%)$ yang berada pada kelompok rata-rata hitung, 27 siswa $(38,58 \%)$ siswa memperoleh skor di bawah ratarata hitung, dan 32 siswa $(45,71 \%)$ memperoleh skor di atas rata-rata.

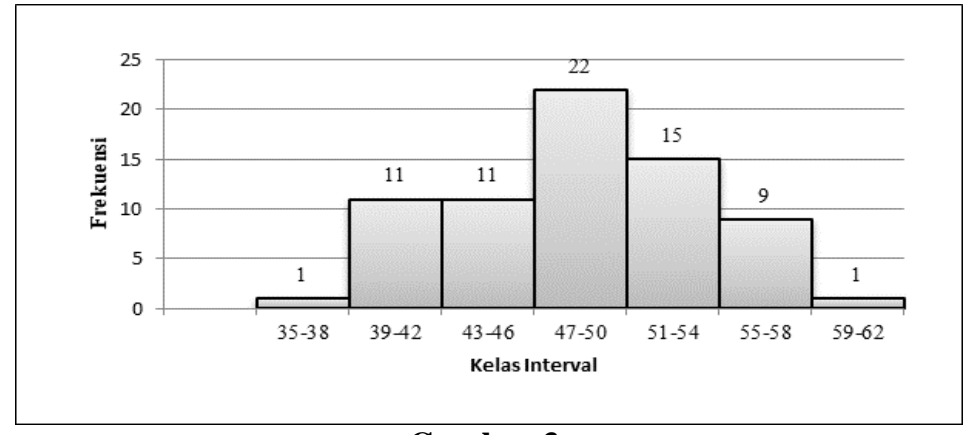

Gambar 3.

Kemampuan Berpikir Kreatif Kelas Eksperimen $\left(\mathbf{X}_{1} \mathbf{A}_{1}\right)$

Berdasarkan diagram di atas, menunjukkan bahwa 22 siswa $(31,43 \%)$ yang berada pada kelompok rata-rata hitung, 23 siswa $(32,86 \%)$ siswa memperoleh skor di bawah ratarata hitung, dan 25 siswa $(35,71 \%)$ memperoleh skor di atas rata-rata.

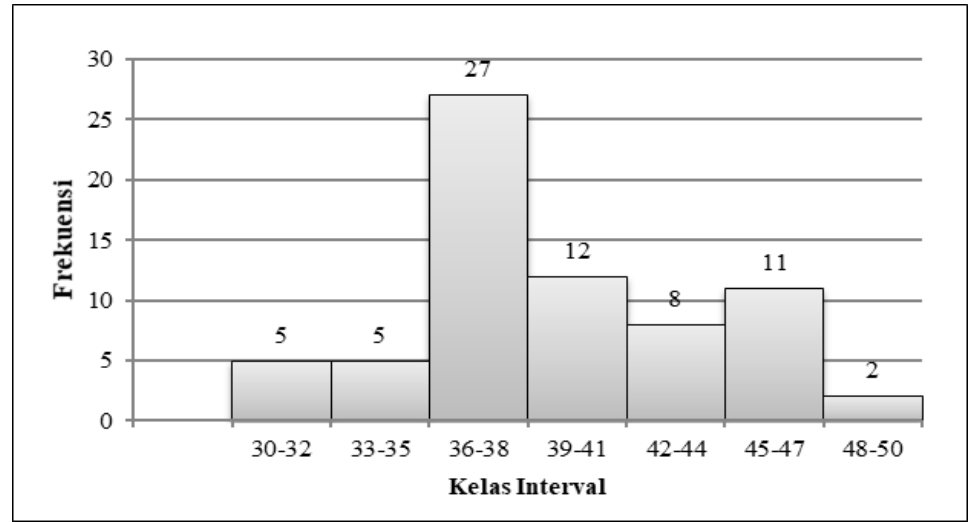

Gambar 4.

Kemampuan Berpikir Kreatif Kelas Kontrol (X1A2)

Berdasarkan diagram di atas, menunjukkan bahwa 12 siswa $(17,14 \%)$ yang berada pada kelompok rata-rata hitung, 37 siswa $(52,86 \%)$ siswa memperoleh skor di bawah ratarata hitung, dan 21 siswa (30\%) memperoleh skor di atas rata-rata. 


\section{Pengujian Hipotesa Pertama}

Hasil pengujian hipotesis pertama menggunakan analisis anava-satu jalan diperoleh hasil output SPSS 20 for windows sebagai berikut:

Tabel 2.

Output SPSS Uji Hipotesis Pertama

\begin{tabular}{|c|c|c|c|c|c|}
\hline \multicolumn{6}{|c|}{ Dependent Variable: Keterampilan Proses Sains } \\
\hline Source & $\begin{array}{l}\text { Type III Sum } \\
\text { of Squares }\end{array}$ & df & Mean Square & $\mathbf{F}$ & Sig. \\
\hline Corrected Model & $3312.579^{\mathrm{a}}$ & 1 & 3312.579 & 50.964 & .000 \\
\hline Intercept & 842270.579 & 1 & 842270.579 & 12958.236 & .000 \\
\hline A & 3312.579 & 1 & 3312.579 & 50.964 & .000 \\
\hline Error & 8969.843 & 138 & 64.999 & & \\
\hline Total & 854553.000 & 140 & & & \\
\hline Corrected Total & 12282.421 & 139 & & & \\
\hline
\end{tabular}

Berdasarkan hasil perhitungan dengan SPSS 20 for Windows diatas ternyata nilai ${ }^{\mathrm{F}_{\text {hit }}=}$ 50,964 dengan signifikansi 0,00 Sehingga $\mathrm{H}_{0}$ ditolak dan $\mathrm{H}_{1}$ diterima. Jadi dapat dikatakan bahwa: terdapat perbedaan keterampilan proses sains siswa yang mengikuti pembelajaran dengan metode karya kelompok dengan siswa yang mengikuti pembelajaran dengan metode diskusi.Kesimpulan dari pengujian hipotesis di atas menjadi bukti bahwa keterampilan proses sains siswa yang mengikuti metode pembelajaran karya kelompok lebih unggul dari siswa yang mengikuti pembelajaran diskusi.Temuan pengujian penelitian diatas, diperkuat dengan temuan teoritik yang menyatakan bahwa metode pembelajaran karya kelompok adalah salah satu metode pembelajaran yang berpusat kepada siswa (student center) dimana siswa diberikan tugas untuk menyelesaikan suatu proyek melalui kerja sama antara kelompok (Suyono dan Hariyanto, 2015).

Dari konsep tersebut ada dua hal yang perlu dipahami yaitu: Pertama, metode karya kelompok menekankan kepada proses keterlibatan siswa untuk menemukan materi, artinya proses belajar diorientasikan pada proses pengalaman secara langsung. Kedua, metode karya kelompok mondorong agar siswa dapat bekerja sama menemukan dan menyelesaikan tugas kelompoknya secara bersama-sama. Temuan dari hasil penelitian ini, sejalan dengan pernyataan Sagala (2006) bahwa metode karya kelompok adalah cara pembelajaran dimana siswa dalam kelas dibagi dalam beberapa kelompok, dimana setiap kelompok dipandang sebagai satu kesatuan tersendiri untuk mempelajari materi pelajaran yang telah ditetapkan untuk diselesaikan secara bersama-sama.

Secara konsepual metode karya kelompok memiliki keunggulan (Suyono dan Hariyanto, 2015) antara lain: (1) Siswa akan terdorong untuk mempraktikan pembelajaran aktif; (2) Siswa merasa tertantang untuk menyelesaikan tugasnya; (3) Siswa terbiasa untuk menggunakan sumber belajar yang tersedia di luar sekolah; (4) Membantu siswa untuk menyelesaikan tugas-tugas yang kompleks. Selain itu penerapan karya kelompok dapat mengembangkan perilaku gotong royong dan demokratis serta memacu siswa untuk aktif belajar.Berdasarkan uraian diatas, metode karya kelompok merupakan suatu sistem pembelajaran yang didasarkan pada kerja sama dalam kelompok untuk menyelesaikan tugastugas yang berkaitan dengan penemuan materi.

Selain temuan penelitian dan dukungan teoritis diatas juga diperkuat oleh temuantemuan peneliti terdahulu antara lain: (a) Ergül (2011) mengenai pengaruh dari inquiry-based pada keterampilan proses sains dan sikap sains menunjukkan bahwa penggunaan metode pengajaran berbasis inquiry secara signifikan meningkatkan keterampilan proses sains siswa dan sikap ilmiah. 
Pengaruh Metode Pembelajaran Karya Kelompok Terhadap Keterampilan Proses Sains Dengan

Kovariabel Kemampuan Berpikir Kreatif Siswa .... (Theodora S. N. Manu, F. Th. Nomleni)

\section{Pengujian Hipotesis Kedua}

Hasil pengujian hipotesis kedua menggunakan Anacova satu jalan-satu covariabel diperoleh hasil output SPSS sebagai berikut:

Tabel 3.

Output SPSS Uji Hipotesis Kedua

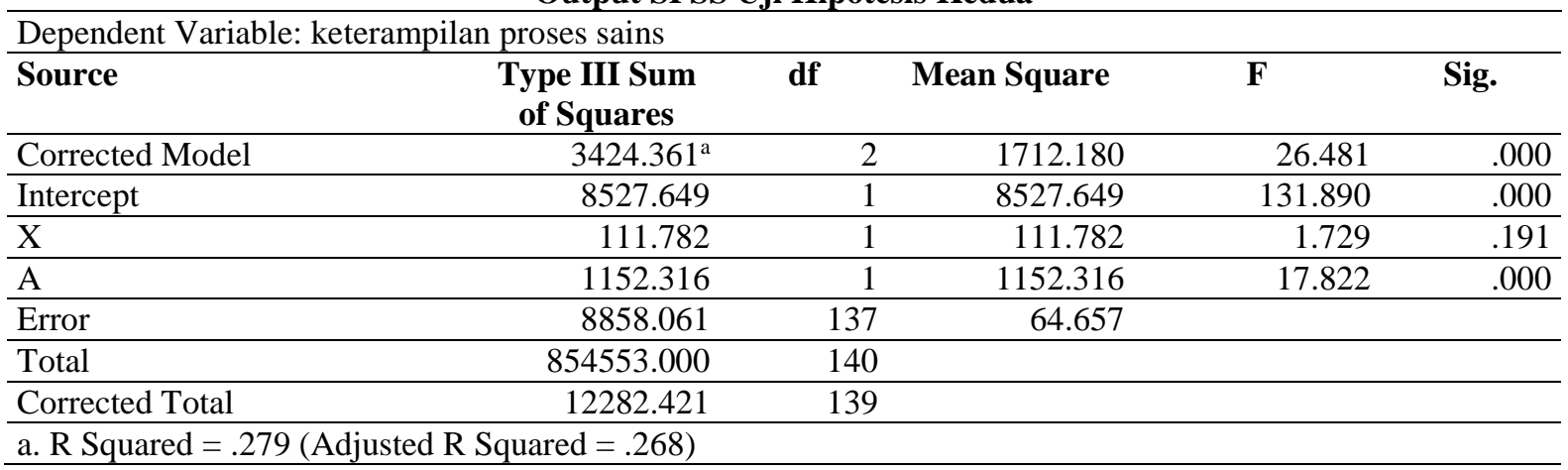

Berdasarkan hasil perhitungan dengan SPSS 20 for Windows diatas ternyata nilai $\mathrm{F}_{\text {hit }}$ $=17,822$ dengan signifikansi 0,00 Sehingga $\mathrm{H}_{0}$ ditolak dan $\mathrm{H}_{1}$ diterima. Jadi dapat dikatakan bahwa: terdapat perbedaaan keterampilan proses sains siswa yang mengikuti pembelajaran dengan metode karya kelompok dengan siswa yang mengikuti pembelajran dengan metode diskusi, setelah kovariabel kemampuan berpikir kreatif dikendalikan

Temuan hasil penelitian di atas menunjukkan bahwa kemampuan berpikir kreatif juga mempengaruhi keterampilan proses sains siswa. Menurut Dahar (1996), keterampilan proses sains adalah kemampuan siswa untuk menerapkan metode ilmiah dalam memahami, mengembangkan dan menemukan ilmu pengetahuan. Keterampilan proses sains sangat penting bagi setiap siswa sebagai bekal untuk menggunakan metode ilmiah dalam mengembangkan sains serta diharapkan memperoleh pengetahuan baru atau mengembangkan pengetahuan yang telah dimiliki.

Suastra (2006) menyatakan: kemampuan berpikir kreatif merupakan salah satu jenis kemampuan yang dimiliki oleh siswa yang sangat dibutuhkan dalam belajar. Kemampuan berpikir kreatif merupakan respon dari stimulus terhadap suatu objek yang merupakan wawasan pola pikir seorang siswa yang dinyatakan dalam bentuk variasi dari respon tentang hal-hal yang terkait dengan pokok pembicaraan. Kreativitas merupakan bakat yang secara potensial dimiliki oleh setiap orang, yang dapat diidentifikasi dan dipupuk melalui pendidikan yang tepat (Munandar, 2004).

Hasil penelitian ini menunjukkan bahwa telah terbukti adanya perbedaaan keterampilan proses sains siswa yang mengikuti pembelajaran dengan metode karya kelompok dengan siswa yang mengikuti pembelajaran dengan metode ceramah, setelah kovariabel kemampuan berpikir kreatif dikendalikan.Tentunya hasil penelitian ini membuktikan bahwa kegiatan pembelajaran yang pendekatannya berpusat pada siswa sangat cocok untuk mengembangkan keterampilan proses sains dan kemampuan berpikir kreatif yang dimiliki siswa. Temuan ini sejalan dengan hasil penelitian Rini, R., \& Mawardi, M. (2015: 106) yang menemukan bahwa keterampilan saintifik membantu siswa untuk berpikir secara ilmiah dalam menghadapi dan memecahkan masalah. Dengan demikian siswa dapat lebih kritis terhadap suatu masalah yang dihadapi.

\section{Pengujian Hipotesis Ketiga}

Hasil pengujian hipotesis ketiga menggunakan regresi diperoleh hasil output SPSS sebagai berikut: 
Tabel 4.

Output SPSS Uji Hipotesis Ketiga

\begin{tabular}{|c|c|c|c|c|c|c|}
\hline \multicolumn{7}{|c|}{ ANOVA $^{a}$} \\
\hline & & $\begin{array}{l}\text { Sum of } \\
\text { Squares }\end{array}$ & df & $\begin{array}{c}\text { Mean } \\
\text { Square }\end{array}$ & $\mathbf{F}$ & Sig. \\
\hline \multirow{3}{*}{1} & Regression & 2272.045 & 1 & 2272.045 & 31.322 & $.000^{\mathrm{b}}$ \\
\hline & Residual & 10010.377 & 138 & 72.539 & & \\
\hline & Total & 12282.421 & 139 & & & \\
\hline
\end{tabular}

a. Dependent Variable: KETERAMPILAN PROSES SAINS (Y)

b. Predictors: (Constant), KEMAMPUAN BERPIKIR KREATIF (X)

\begin{tabular}{|c|c|c|c|c|c|c|c|c|c|}
\hline \multicolumn{10}{|c|}{ Model Summary ${ }^{b}$} \\
\hline \multirow[t]{2}{*}{ Model } & \multirow[t]{2}{*}{$\mathrm{R}$} & \multirow[t]{2}{*}{ R Square } & \multirow{2}{*}{$\begin{array}{l}\text { Adjusted } \\
\text { R Square }\end{array}$} & \multirow{2}{*}{$\begin{array}{l}\text { Std. Error } \\
\text { of the } \\
\text { Estimate }\end{array}$} & \multicolumn{5}{|c|}{ Change Statistics } \\
\hline & & & & & $\begin{array}{l}\text { R Square } \\
\text { Change }\end{array}$ & F Change & df1 & df2 & $\begin{array}{c}\text { Sig. F } \\
\text { Change }\end{array}$ \\
\hline 1 & $.430^{\mathrm{a}}$ & .185 & .179 & 8.517 & .185 & 31.322 & 1 & 138 & .000 \\
\hline \multicolumn{10}{|c|}{ a. Predictors: (Constant), KEMAMPUAN BERPIKIR KREATIF (X) } \\
\hline \multicolumn{10}{|c|}{ b. Dependent Variable: KETERAMPILAN PROSES SAINS (Y) } \\
\hline
\end{tabular}

Nilai $\mathrm{F}_{\text {hit }}$ regresi $=31,322$ dengan sig. 0,000 artinya nilai sig $<0,005$ sehingga hipotesis nol ditolak dan hipotesis alternatif diterima. Dengan demikian, terdapat kontribusi kovariabel kemampuan berpikir kreatif terhadap keterampilan proses sains dalam mata pelajaran Biologi.

Untuk mengetahui kontribusi variabel prediktor terhadap kriterium, nilai koefisien korelasinya dikuadratkan $r^{2}=(0,430)^{2}=0,185$ atau $18,5 \%$; ini berarti sumbangan atau kontribusi kemampuan berpikir kreatif terhadap keterampilan proses sains adalah sebesar $18,5 \%$ sedangkan residunya $81,5 \%$ dijelaskan oleh variabel lain yang tidak termasuk dalam penelitian ini.

Korelasi antara kemampuan kemampuan berpikir kreatif sebesar 0,430 dengan koefisien determinasi sebesar $18,5 \%$. Hal ini menunjukkan hubungan yang signifikan antara kemampuan berpikir kreatif siswa dengan keterampilan proses sains.

Dari temuan hasil penelitian untuk ketiga hipotesis, dapat dikatakan bahwa metode karya kelompok berpengaruh terhadap berpikir kreatif dan keterampilan proses sains. Temuan penelitian sejalan/relevan dengan penelitian yang dilakukan Livingstone \& Lynch (2000) mengenai Group Project Work and Student-centred Active Learning: Two different experiences disimpulkan pembelajaran kelompok memberikan pengalaman berharga kepada peserta didik karena keterlibatan dalam bekerja sama untuk menyelesaikan tugas/proyek dan dapat memotivasi mereka untuk menyelesaikan tugas yang diberikan.

Penelitian mengenai kontribusi berpikir kreatif juga dilakukan oleh: Amtiningsih, Dwiastuti \& Puspita Sari (2016) melalui judul penelitian tentang Peningkatan Kemampuan Berpikir Kreatif melalui Penerapan Guided Inquiry dipadu Brainstorming pada Materi Pencemaran Air memperoleh hasil pembelajaran menggunakan guided inquiry dipadu brainstorming efektif dan berkontribusi positif untuk meningkatkan kemampuan berpikir kreatif.

Kajian mengenai kreatifitas siswa dan kemampuan kelompok juga ditulis oleh Taggar (2002) mengenai: Individual creativity and group Ability to Utilize Individual Creative Resources: A Multilevel Model. Diperoleh bahwa pada anggota tim aspek kogntif dan perilaku relevan/ sesuai dengan kreativitas individual. Proses yang berlangsung dalam kerja tim memungkinkan adanya dukungan dari setiap individu untuk mendorong kreatifitas dalam kelompok/tim.

Pandangan terhadap kreativitas dalam lingkungan belajar di kelas juga diteliti oleh: Fleith (2010) melalui penelitian yang berjudul: Teacher and student perceptions of creativity 
Pengaruh Metode Pembelajaran Karya Kelompok Terhadap Keterampilan Proses Sains Dengan

Kovariabel Kemampuan Berpikir Kreatif Siswa .... (Theodora S. N. Manu, F. Th. Nomleni)

in the classroom environment dimana persepsi guru dan siswa tentang karakteristik yang merangsang atau menghambat perkembangan kreativitas di lingkungan kelas. Temuan menunjukkan bahwa baik guru dan siswa percaya bahwa lingkungan kelas yang meningkatkan kreativitas memberi pilihan kepada siswa, menerima gagasan yang berbeda, meningkatkan kepercayaan diri, dan berfokus pada kekuatan dan minat siswa. Di sisi lain, di lingkungan yang menghambat kreativitas seperti gagasan yang diabaikan dan guru yang mengendalikan lingkungan kelas.

Dari kajian di atas, penurunan atau peningkatan nilai kemampuan berpikir kreatif akan cenderung pula diikuti peningkatan atau penurunan keterampilan proses sains siswa dalam pelajaran biologi. Kemampuan berpikir kreatif memberikan kontribusi 18,5\% kepada keterampilan proses sains. Ini berarti $18,5 \%$ dari perubahan yang berupa peningkatan atau penurunan keterampilan proses sains dikontribusi oleh kemampuan berpikir kreatif siswa sedangkan sisanya dipengaruhi oleh faktor-faktor lain. Meskipun kemampuan berpikir kreatif memberikan kontribusi yang kecil terhadap keterampilan proses sains akan tetapi tetap memberikan pengaruh yang signifikan terhadap keterampilan proses sains siswa.

\section{SIMPULAN DAN SARAN}

Simpulan dari penelitian ini ialah sebagai berikut: terdapat perbedaan keterampilan proses sains siswa yang mengikuti pembelajaran dengan metode karya kelompok dengan siswa yang mengikuti pembelajaran dengan metode diskusi;terdapat perbedaaan keterampilan proses sains siswa yang mengikuti pembelajaran dengan metode karya kelompok dengan siswa yang mengikuti pembelajran dengan metode diskusi, setelah kovariabel kemampuan berpikir kreatif dikendalikan; terdapat kontribusi kovariabel kemampuan berpikir kreatif terhadap keterampilan proses sains.

Saran dari hasil penelitian: Bagi Guru:dapat menerapkan metode pembelajaran yang inovatif salah satunya metode karya kelompok sehingga pelaksanaannya kegiatan belajar mengajar menjadi lebih efektif dan efesien; Bagi Siswa, perlu lebih meningkatkan rasa tanggung jawab terhadap proses pembelajaran, metode pembelajaran karya kelompok dapat memberi kesempatan kepada siswa secara aktif untuk mengembangkan potensiyang dimiliki dalam usaha mengkonstruksi sendiri pengetahuannya; Bagi para peneliti lain, perlu melakukan penelitian lanjutan yang lebih luas diluar variabel penelitian ini agar dunia pendidikan lebih terbuka dan memahami upaya dalam meningkatkan hasil belajar agar mutu pendidikan Indonesia semakin lebih baik kedepan.

\section{UCAPAN TERIMAKASIH}

Ucapan terimakasih diberikan kepada: (1) DRPM Ditjen Penguatan Risbang, atas bantuan dana hibah Penelitian Dosen Pemula tahun 2017 yang diberikan kepada peneliti sehingga penelitian ini dapat berjalan dengan baik;(2) Pihak SMA Negeri 7 Kota Kupang terdiri dari kepala sekolah, guru mata pelajaran biologi dan siswa-siswi atas bantuan dan kerjasama dalam pelaksanaan penelitian.

\section{DAFTAR PUSTAKA}

Amtiningsih, S. Dwiastuti, S. Puspita Sari, D. 2016. Peningkatan Kemampuan Berpikir Kreatif melalui Penerapan Guided Inquiry dipadu Brainstorming pada Materi Pencemaran Air.Proceeding Biology Education Conference. 13 (1). 868-872

Candiasa.2011. Statistik Multivariat Disertai Aplikasi SPSS. Singaraja: Undiksha Press. 
Dahar, R.W. 1996. Teori-Teori Belajar. Jakarta: Erlangga

Dantes, N. 2012.Metode Penelitian. Yogyakarta: Andi

Deta, Suparmi, \& Widha. 2013. Pengaruh metode inkuiri terbimbing dan proyek, kreativitas, serta keterampilan proses sains terhadap prestasi belajar siswa. Jurnal pendidikan fisika Indonesia. 9 (1). 28-34

Dimyati dan Mudjiono. 2009. Belajar dan Pembelajaran. Jakarta: Rineka Cipta

Ergül R., Simsekli, Y., Sevgül .C., Zehra, O \& Göçmençeleb, S.,2011. Effects of inquirybased Science teaching on elementary School students' science process Skills and science attitudes. Bulgarian journal of science and education policy (bjsep), 5 (1). 4868

Fleith (2010). Teacher and student perceptions of creativity in the classroom environment. Journal Roeper Review. 22 (3). 148-153

Koyan, I.W. 2012.Statistik Pendidikan (Teknik Analisis Data Kuantitatif). UndikshaPres

Livingstone, D \& Lynch,K (2000). Group Project Work and Student-centred Active Learning: Two different experiences. Journal Studies in Higher Education. 25 (3). 325-345

Maradona.2013. Analisis Ketrampilan Proses Sains Siswa Kelas XI IPA SMA Islam Samarinda Pada Pokok Bahasan Hidrolisis Melalui Metode Eksperimen.Prosiding seminar nasional.

Mulyasa, E. 2009. Standar Kompetensi dan Sertifikasi Guru. Bandung: Remaja Rosdakarya.

Munandar, S.C.U. 2004.Pengembangan Kreativitas Anak Berbakat. Jakarta: Rineka Cipta.

Rahmadani, N., \& Anugraheni, I. (2017). Peningkatan Aktivitas Belajar Matematika Melalui Pendekatan Problem Based Learning Bagi Siswa Kelas 4 SD. Scholaria: Jurnal Pendidikan Dan Kebudayaan, 7(3), 241-250.

Rini, R., \& Mawardi, M. (2015). Peningkatan Keterampilan Proses Saintifik dan Hasil Belajar Siswa Kelas 4 SDN Slungkep 02 Tema Peduli Terhadap Makhluk Hidup Menggunakan Model Problem Based Learning. Scholaria: Jurnal Pendidikan dan Kebudayaan, 5(1), 103-113.

Sagala, S. 2006. Konsep dan Makna Pembelajaran.Bandung : Alfabeta

Suastra, I W. 2006. Mengembangkan Kemampuan Berpikir Kreatif Melalui Pembelajaran Sains. Jurnal IKA Singaraja: Ikatan Keluarga Alumni Universitas Pendidikan Ganesha. 4 (2). 23-34

Suyono \& Hariyanto. 2015. Implementasi Belajar dan Pembelajaran. Bandung: PT Remaja Rosdakarya

Taggar, S. (2002). Individual creativity and group Ability to Utilize Individual Creative Resources: A Multilevel Model. Acad Manage Journal. 45 (2). 315-330 